\title{
HEALTH INITIATIVES IN NATIONAL PAN-AMERICAN SWIMMING FEDERATIONS
}

\author{
INICIATIVAS DE SAÚDE NAS FEDERAÇÕES NACIONAIS DE NATAÇÃO PAN-AMERICANAS \\ INICIATIVAS DE SALUD EN LAS FEDERACIONES NACIONALES DE NATACIÓN PANAMERICANAS
}

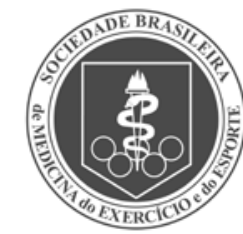

Original Article

ARtigo ORIGINAL

Artículo Original
Clarence Perez Diaz'

(Sport Scientist)

Juan Carlos De la Cruz Marquez ${ }^{1}$ (Doctor).

Nuria Rico Castro²

(Statistical)

Belén Cueto Martín

(Sport Scientist)

1. University of Granada, Faculty of Sport Science, Department of Physical Education; Granada, Spain. 2. University of Granada, Department of Statistics and Operations Research;

Granada, Spain.

\section{Correspondence:}

International Federation of Sports Medicine Maison du sport international. Av. de la Rhodanie 54, 1007 Lausanne., Switzerland. clarenceperezdiaz@fims.org

\begin{abstract}
Introduction: National Swimming Federations (NFs) supervise a large number of athletes and have the duty to protect their health that implies also the opportunity to improve public health. Objective: 1) To determine if the health professionals, the priorities, activities, and researches of the Pan-American NFs are focused on protecting athletes' health and promoting the health of the population in general. 2) To determine if the FINA rules, projects and programs are applied. Method: A cross-sectional descriptive survey was carried out among the 45 Pan-American NFs requesting information on the profile of the health professionals (dimension 1; D1), on programs, activities and research to promote health measures (dimension 2; D2), and on the importance of Pan-American NFs for the health of athletes and for the promotion of health in society in general (dimension 3; D3). We performed a similarity study according to the Rogers-Tanimoto coefficient (D1 and D2) and the chi-squared test $\left(X^{2}\right)(D 3)$. Results: Thirty NFs answered the survey (response rate: 66.6\%). For each dimension, the NFs were classified into five groups ( $A, B, C, D, E)$. Among the NFs, 33.3\% have physicians and $33.3 \%$ have physical therapists. In each of the dimensions, Group A accounted for the majority of NFs but their results were lower. The groups with the highest rates in each dimension contained a maximum of two NFs. The health of the elite athletes was ranked as the fourth most important issue. The health of the recreational athletes and the health of the general population had the lowest priority. Drowning prevention programs were the most common. Conclusions: Pan-American NFs have few medical resources and only a few have injury prevention programs for elite athletes. There is a need to improve health promotion programs to achieve relevant social outcomes.
\end{abstract}

Keywords: swimming; health promotion; athletes; public health.

\section{RESUMO}

Introdução: As Federações Nacionais de Natação (FN) supervisionam um elevado número de atletas e têm o dever de proteger sua saúde, implicando também a oportunidade de melhorar a saúde pública. Objetivo: 1) Determinar se os profissionais de saúde, as prioridades, atividades e pesquisas das FN pan-americanas estão focados na proteção da saúde dos atletas e na promoção da saúde da população. 2) Determinar se as regras, os projetos e programas da FINA são aplicados. Método: Uma pesquisa transversal descritiva foi distribuída entre as 45 FN pan-americanas, solicitando informações sobre o perfil dos profissionais de saúde (dimensão 1; D1), sobre programas, atividades e pesquisas de promoção de medidas de saúde (dimensão 2; D2) e sobre a importância das FN pan-americanas para a saúde dos atletas, e para a promoção da saúde na sociedade em geral (dimensão 3; D3). Realizamos um estudo de similaridade de acordo com o coeficiente de Rogers-Tanimoto (D1 e D2) e o teste do qui quadrado ( $x^{2}$ ) (D3). Resultados: Trinta FN responderam a pesquisa (taxa de resposta: 66,6\%). Para cada dimensão, as FN foram classificadas em cinco grupos ( $A, B, C, D, E)$. Entre as FN, 33,3\% têm médicos e 33,3\% têm fisioterapeutas. Em cada uma das dimensões, o Grupo A, representou a maioria das $F N$, mas seus resultados foram inferiores. Os grupos com maiores taxas em cada dimensão continham, no máximo, duas FN. A saúde dos atletas de elite foi classificada como a quarta questão mais importante. A saúde dos atletas amadores e a da população tiveram prioridade mais baixa. Os programas de prevenção de afogamento foram os mais comuns. Conclusões: As FN pan-americanas têm poucos recursos médicos e apenas algumas delas têm programas de prevenção de lesões para os atletas de elite. É necessário melhorar os programas de promoção da saúde para obter resultados sociais relevantes.

Descritores: natação; promoção da saúde; atletas; saúde pública.

\section{RESUMEN}

Introducción: Las Federaciones Nacionales de Natación (FN) supervisan un alto número de atletas y tienen el deber de proteger su salud, implicando también la oportunidad de mejorar la salud pública. Objetivos: 1) Determinar si los profesionales de salud, las prioridades, actividades e investigaciones enfocan la promoción de la salud de los atletas y de la población. 2) Determinar si las reglas, los proyectos y programas de la FINA se aplican. Método: Una encuesta transversal descriptiva fue distribuida entre las 45 FN panamericanas, solicitando informaciones sobre el perfil de los profesionales de salud (dimensión 1, D1), sobre programas, actividades y pesquisas de promoción de medidas de salud (dimensión 2, D2) y sobre la importancia de las FN panamericanas para la salud de los atletas y para la promoción de la salud en la sociedad en general (dimensión 3, D3). Se realizó un estudio de similitud según el 
coeficiente de Rogers-Tanimoto (D1 y D2) y la prueba del Chi cuadrado ( $\left.x^{2}\right)$ (D3). Resultados: Treinta FN respondieron (tasa de respuesta: 66,6\%). Para cada dimensión, las FN se clasificaron en cinco grupos $(A, B, C, D, E)$. Entre las FN, el 33,3\% disponen de médicos y el 33,3\% de fisioterapeutas. En cada una de las dimensiones, el grupo A representó la mayoría de las FN, pero sus resultados fueron inferiores. Los grupos con mayores tasas en cada dimensión contenían como máximo dos FN. La salud de los atletas de elite fue clasificada como la cuarta cuestión más importante. La salud de los atletas aficionados y de la población tuvo prioridades más bajas. Los programas de prevención del ahogamiento fueron los más comunes. Conclusiones: Las FN panamericanas disponen de escasos recursos médicos y solo algunas tienen programas de prevención de lesiones para los atletas de elite. Es necesario mejorar los programas de promoción de la salud para obtener resultados sociales relevantes.

\section{Descriptores: natación; promoción de la salud; atletas; salud pública.}

\section{INTRODUCTION}

The International Swimming Federations (FINA), Continental Swimming Federations (CFs) and National Swimming Federations (NFs) oversee a high number of athletes and have a duty to protect their health ${ }^{1}$. At the same time they have an opportunity to leverage the health benefits of their sport to improve public health².

FINA's CF in the Americas, the Union Americana de Natation (UANA) adheres to the FINA Medical rules which emphasise the protection and promotion of the athletes' health during training and competition and encourage NFs to take measures to minimise the risk of injuries and illness through the participation of sports physicians ${ }^{1}$. Other international and continental federations ("IFs") such as FIFA', $\mathrm{FIS}^{4}$, IAAF", UEFA ${ }^{6,7}$, $\mathrm{HHF}^{8}, \mathrm{FISA}^{9}$ and $\mathrm{FIVB}^{10}$ have made considerable resources available for research teams in this regard. The IFs aim to protect the health of their elite athletes through a variety of activities ${ }^{11}$.

FINA has sought to focus on injury prevention; since the 2009 FINA World Championships (Aquatics), studies have been conducted by FINA during each FINA World Aquatic Championships in relation to injury and illness ${ }^{12,13}$.

FINA in partnership with, among others, UNESCO, UNICEF, the UN and the IOC has created "Swimming for All" programmes, the main goals of which are to reduce global drowning rates and promote a healthier lifestyle ${ }^{14}$. In addition, FINA invites its NFs to the FINA Sport Medicine Congress every 2-3 years at which sports medicine topics such as health promotion in the general population and the protection of the elite athletes' health are addressed. At a Pan American level, UANA endeavours to develop aquatic sports throughout the Americas by assisting in the hosting of regional championships and by conducting clinics and other educational seminars throughout the Americas ${ }^{15}$. However UANA does not yet have a technical body in charge of medical matters.

One of the aims of the study is to question the extent to which these FINA rules, projects and programmes trickle down to the Pan American NFs? The medical capabilities of Pan American NFs and their role in health promotion is an area of which little is known. The second aim of the study is to bridge this knowledge gap by examining how Pan American NFs are structured from a medical perspective, determining their health priorities and identifying their health programmes, activities and initiatives.

\section{METHODOS}

The health representatives or designated person of each of the 45 Pan American NFs were invited to participate in a detailed descriptive transversal online survey, assuring the anonymity of the respondents and respecting the applicable regulations of the $\mathrm{EU}$ in relation to data protection (the ethical clearance number of the study is UGR. 58CEIH/2014).
An email invitation was sent out on the 1st of October 2014. The survey was also distributed in person at one occasion (the FINA Aquatics Convention 2015). If a question was unanswered, it was excluded from the analysis. The first NF submitted their responses in October 2014 and the last in February 2015.

The survey was designed based on existing studies carried by the International Sport Medicine Federation (FIMS) ${ }^{16}$ and the study of Mountjoy and Junge ${ }^{11}$ on the IFs and was tailored to the specific goals of this study. A pilot study was carried out by two independent experts in the area of Sport Science from the University of Granada through a blind review.

A statistical validity and reliability was obtained (Cronbach a coefficient of 0.8642 for $n=15$ ). The survey was created using the free software platform LimeSurvey (GNU /GPL v2) and was available at the Center for Computing and Network Services, (University of Granada).

The questionnaire was available in English, Spanish and French.-

\section{Statistic analysis}

The raw data was exported from the survey tools and analysed (blind method) The questionnaire was built using a blend of dichotomous and five-point Likert scale response alternatives. Using the agglomerative hierarchical clustering method, interlinkage among NFs was determined in order to categorise the NFs into the 5 groups. Data were processed using Excel and SPSS v20.0:0.

The NFs have been classified based on their responses to three different health related topics (Significance was accepted at $p<0.05$ ).

Further to the dendogram results of each of the three dimensions, 5 groups of NFs (A to E) were established for each dimension (Table 1).

Dimension 1. Classification of the NFs in relation to the medical personnel within their national team or national federation (Table 2 and Table 3).

Dimension 2. Classification in relation to health programmes, researches and guidelines of the NFs (Table 4).

To carry out the classifications of Dimensions 1 and 2, a study of similarities of each Dimension was performed using the pairing measure of Rogers-Tanimoto. This method takes into consideration the existing agreement among the subjects when factors coincide and when they are absent. Dendrograms based on the linkage of measures (between groups) were used.

Dimension 3. Classification of health priorities among the Pan American NFs (Table 5).

Closed - ended questions (on the topics of table 5) were structured using a five-point scale where, $5=$ top priority, $4=$ very important, 3 = important, 2 = low importance, $1=$ not important, $0=$ do not know. The average results among the NFs were then determined and graded according to a maximum value of 5 . For the analysis of this dimension the Chi-squared measure was used. 
Table 1. Classification of the NFs Groups according of Rogers-tanimoto measure and the Chi-squared measure.

\begin{tabular}{|c|c|c|c|c|c|c|c|c|}
\hline \multicolumn{3}{|c|}{$\begin{array}{c}\text { Medical personnel } \\
\text { Rogers-tanimoto measure }\end{array}$} & \multicolumn{3}{|c|}{$\begin{array}{c}\text { Programmes } \\
\text { Rogers-tanimoto measure }\end{array}$} & \multicolumn{3}{|c|}{$\begin{array}{c}\text { Priorities } \\
\text { Chi-squared measure }\end{array}$} \\
\hline G & & $\mathrm{F}$ & G & & $\mathrm{F}$ & G & & $\mathrm{NF}$ \\
\hline $\begin{array}{c}\text { A } \\
19\end{array}$ & $\begin{array}{l}\text { Antigua \& Barbuda, } \\
\text { BarbadosBolivia, } \\
\text { Chile, Costa Rica, } \\
\text { Dominican Republic, } \\
\text { Grenada, Haiti, } \\
\text { Honduras, }\end{array}$ & $\begin{array}{l}\text { Republic of Panama, } \\
\text { Peru, Turks and } \\
\text { Caicos Islands, } \\
\text { Uruguay, Aruba, } \\
\text { Canada, Curacao, } \\
\text { Saint Lucia, Puerto } \\
\text { Rico, St. Kitts \& Nevis }\end{array}$ & $\begin{array}{c}\text { A } \\
20\end{array}$ & $\begin{array}{l}\text { Antigua \& Barbuda, } \\
\text { Argentina, Barbados, } \\
\text { Bolivia, Chile, } \\
\text { Grenada, Honduras, } \\
\text { Republic of Panama, }\end{array}$ & $\begin{array}{l}\text { Paraguay, Peru, Turks } \\
\text { and Caicos Islands, } \\
\text { Uruguay, Aruba, } \\
\text { Bahamas, Canada, } \\
\text { Canada 2, Curacao, } \\
\text { Puerto Rico, St. Kitts } \\
\text { \& Nevis }\end{array}$ & $\begin{array}{c}\text { A } \\
26\end{array}$ & $\begin{array}{l}\text { Antigua \& Barbuda, } \\
\text { Barbados, } \\
\text { Bolivia, Costa Rica, } \\
\text { Dominican Republic, } \\
\text { El Salvador, Grenada, } \\
\text { Guatemala, Haiti, } \\
\text { Honduras, }\end{array}$ & $\begin{array}{l}\text { Jamaica, Republic of } \\
\text { Panama, Paraguay, } \\
\text { Peru, Turks and Caicos } \\
\text { Islands, Uruguay, } \\
\text { Aruba, Bahamas, } \\
\text { Canada, Canada } \\
\text { 2, Cayman Islands, } \\
\text { Curacao, British Virgin } \\
\text { Islands, Saint Lucia, St. } \\
\text { Kitts \& Nevis, USA }\end{array}$ \\
\hline $\begin{array}{l}B \\
4\end{array}$ & \multicolumn{2}{|c|}{ Argentina, Colombia, Guatemala, Canada 2} & $\begin{array}{l}B \\
3\end{array}$ & \multicolumn{2}{|c|}{ Colombia, Cayman Islands, Saint Lucia } & $\begin{array}{l}B \\
1\end{array}$ & \multicolumn{2}{|l|}{ Argentina } \\
\hline $\begin{array}{l}C \\
4 \\
\end{array}$ & \multicolumn{2}{|c|}{$\begin{array}{l}\text { El Salvador, Jamaica, Bahamas, Cayman } \\
\text { Islands }\end{array}$} & $\begin{array}{l}C \\
1 \\
\end{array}$ & \multicolumn{2}{|l|}{ Costa Rica } & $\begin{array}{l}C \\
1\end{array}$ & \multicolumn{2}{|l|}{ Chile } \\
\hline $\begin{array}{l}\mathrm{D} \\
1 \\
\end{array}$ & \multicolumn{2}{|l|}{ Paraguay } & $\begin{array}{l}\mathrm{D} \\
4 \\
\end{array}$ & \multicolumn{2}{|c|}{$\begin{array}{l}\text { Dominican Republic, El Salvador, Haiti, } \\
\text { Jamaica }\end{array}$} & $\begin{array}{l}\mathrm{D} \\
1 \\
\end{array}$ & \multicolumn{2}{|l|}{ Colombia } \\
\hline $\begin{array}{l}E \\
1\end{array}$ & \multicolumn{2}{|l|}{ USA } & $\begin{array}{l}E \\
1\end{array}$ & \multicolumn{2}{|l|}{ Guatemala, USA } & $\begin{array}{l}E \\
1\end{array}$ & \multicolumn{2}{|l|}{ Puerto Rico } \\
\hline $\begin{array}{ll}* \\
1\end{array}$ & \multicolumn{2}{|l|}{ British Virgin Islands } & $\begin{array}{ll}* \\
1\end{array}$ & \multicolumn{2}{|l|}{ British Virgin Islands } & & & \\
\hline 29 & & & 29 & & & 30 & & \\
\hline
\end{tabular}

*NA: Do not know or not available. The grey groups are the most highly rated groups.

Table 2. Percentage of medical personnel in the NFs of each group.

\begin{tabular}{|c|c|c|c|c|c|c|c|c|c|c|}
\hline Group & Physio \% & Doctor \% & Nutritionist $\%$ & Psychologist \% & Sport scientist \% & Medical person \% & Administrative staff $\%$ & Medical Commission \% & $\bar{Q}$ & SD \\
\hline$A(17)$ & 0 & 0 & 0 & 0 & 0 & 5.9 & 11.8 & 0 & 2.2 & 4.3 \\
\hline$B(4)$ & 100 & 100 & 100 & 75 & 100 & 0 & 0 & 0 & 59.3 & 49.8 \\
\hline$C(6)$ & 66.7 & 83.3 & 50 & 0 & 0 & 0 & 0 & 0 & 25 & 35.6 \\
\hline $\mathrm{D}(1)$ & 100 & 0 & 100 & 100 & 0 & 100 & 0 & 0 & 50 & 53.4 \\
\hline$E(1)$ & 100 & 100 & 100 & 100 & 100 & 100 & 100 & 100 & 100 & 0 \\
\hline
\end{tabular}

Table 3. Classification of medical personnel in the NFs overall (30 NFs). Rogers-tanimoto measure.

\begin{tabular}{|c|c|c|c|c|c|c|c|c|c|c|c|c|c|c|}
\hline & \multicolumn{2}{|c|}{ A } & \multicolumn{2}{|c|}{ B } & \multicolumn{2}{|c|}{ C } & \multicolumn{2}{|c|}{ D } & \multicolumn{2}{|c|}{$E$} & \multicolumn{2}{|c|}{ NA } & \multicolumn{2}{|c|}{ TOTAL } \\
\hline & $\mathbf{n}$ & $\%$ & $\mathrm{n}$ & $\%$ & $n$ & $\%$ & $\mathrm{n}$ & $\%$ & $\mathrm{n}$ & $\%$ & $\mathrm{n}$ & $\%$ & $n$ & $\%$ \\
\hline & 17 & 56.7 & 4 & 13.3 & 6 & 20 & 1 & 3.33 & 1 & 3.33 & 1 & 3.33 & 30 & 100 \\
\hline Physiotherapist & 0 & 0 & 4 & 13.3 & 4 & 13.3 & 1 & 3.33 & 1 & 3.33 & & & 10 & 33.3 \\
\hline Doctor & 0 & 0 & 4 & 13.3 & 5 & 16.7 & 0 & 0 & 1 & 33.3 & & & 10 & 33.3 \\
\hline Nutritionist & 0 & 0 & 4 & 13.3 & 3 & 10 & 1 & 3.33 & 1 & 33.3 & & & 9 & 30 \\
\hline Psychologist & 0 & 0 & 3 & 10 & 0 & 0 & 1 & 3.33 & 1 & 3.33 & & & 5 & 6.6 \\
\hline Sports Scientist & 0 & 0 & 4 & 13.3 & 0 & 0 & 0 & 0 & 1 & 3.33 & & & 5 & 16.6 \\
\hline Medical Administrative Staff & 2 & 6.7 & 0 & 0 & 0 & 0 & 0 & 0 & 1 & 3.33 & & & 3 & 10 \\
\hline $\begin{array}{l}\text { Med. Personnel in the highest } \\
\text { executive body }\end{array}$ & 1 & 3.3 & 0 & 0 & 0 & 0 & 1 & 3.3 & 1 & 3.3 & & & 3 & 10 \\
\hline Medical Commission & 0 & 0 & 0 & 0 & 0 & 0 & 0 & 0 & 1 & 3.3 & & & 1 & 3.3 \\
\hline$\ddot{x}$ & 0.4 & 1.3 & 2.4 & 7.9 & 1.5 & 5 & 0.5 & 1.7 & 1 & 10.8 & & & 5.7 & 17.9 \\
\hline SD & 0.7 & 2.3 & 1.9 & 6.2 & 2 & 6.6 & 0.5 & 1.7 & 0 & 13 & & & 3.3 & 11.7 \\
\hline
\end{tabular}

NA: Do not know or not available $(n=1 ; 3.3 \%)$.

Table 4. Classification in relation to health programmes/ researches and guidelines of the Pan American NFs. According to the total of NFs. Rogers-tanimoto measure.

\begin{tabular}{|c|c|c|c|c|c|c|c|c|c|c|c|c|c|}
\hline & \multicolumn{2}{|c|}{ A } & \multicolumn{2}{|c|}{ D } & \multicolumn{2}{|c|}{ B } & \multicolumn{2}{|c|}{$E$} & \multicolumn{2}{|c|}{$\mathrm{C}$} & NA & \multicolumn{2}{|c|}{ Total } \\
\hline & $n$ & $\%$ & $\mathrm{n}$ & $\%$ & $\mathrm{~N}$ & $\%$ & $\mathrm{n}$ & $\%$ & $\mathrm{n}$ & $\%$ & \begin{tabular}{|l|l|}
$n$ & $\%$ \\
\end{tabular} & $n$ & $\%$ \\
\hline & 19 & 63.3 & 4 & 13.3 & 3 & 10 & 2 & 6.6 & 1 & 3.3 & \begin{tabular}{|l|l|}
1 & 3.3 \\
\end{tabular} & 30 & 100 \\
\hline Drowning prevention & 8 & 26.6 & 4 & 13.3 & 3 & 10 & 2 & 6.6 & 1 & 3.3 & & 18 & 60 \\
\hline $\begin{array}{c}\text { Injury prevention } \\
\text { by exercise-based } \\
\text { programmes }\end{array}$ & 0 & 0 & 4 & 13.3 & 3 & 10 & 2 & 6.6 & 0 & 0 & & 9 & 30 \\
\hline Inclusion of the elderly & 0 & 0 & 4 & 13.3 & 0 & 0 & 2 & 6.6 & 1 & 3.3 & & 7 & 23.3 \\
\hline $\begin{array}{c}\text { Injury surveillance } \\
\text { during }\end{array}$ & 1 & 3.3 & 1 & 3.3 & 2 & 6.6 & 2 & 6.6 & 0 & 0 & & 6 & 20 \\
\hline Ambassador athletes & 3 & 10 & 2 & 6.6 & 0 & 0 & 1 & 3.3 & 0 & 0 & & 6 & 20 \\
\hline $\begin{array}{c}\text { Pre-participation } \\
\text { medical } \\
\text { Examination } \\
\end{array}$ & 1 & 3.3 & 0 & 0 & 1 & 3.3 & 2 & 6.6 & 0 & 0 & & 4 & 13.3 \\
\hline $\begin{array}{c}\text { Return-to-play } \\
\text { after injury }\end{array}$ & 1 & 3.3 & 0 & 0 & 0 & 0 & 2 & 6.6 & 0 & 0 & & 3 & 10 \\
\hline Obesity or overweight & 0 & 0 & 0 & 0 & 1 & 3.3 & 2 & 6.6 & 0 & 0 & & 3 & 10 \\
\hline $\begin{array}{c}\text { Prevention of chronic } \\
\text { diseases }\end{array}$ & 0 & 0 & 0 & 0 & 0 & 0 & 1 & 3.3 & 1 & 3.3 & & 2 & 6.6 \\
\hline MEDIAN & 1.5 & 5.1 & 1.6 & 5.5 & 1.1 & 3.6 & 1.7 & 5.8 & 0.3 & 1.1 & & 6.4 & 21.4 \\
\hline SD & 2.5 & 8.2 & 1.8 & 5.9 & 1.2 & 4 & 0.4 & $\begin{array}{l}1.4 \\
\end{array}$ & 0.5 & 1.6 & & 4.6 & 15.3 \\
\hline
\end{tabular}

NA: Do not know or not available $(n=1 ; 3.3 \%)$.

\section{RESULTS}

The overall response rate was $66.6 \%$ (30 of the 45 Pan American NFs replied, including responses from both Aquatics Canada ("Canada 2") and Swimming (anada).

Dimension 1. Medical personnel profile (Tables 2 and 3; Figure 1).

Significantly, one of the two groups with the lowest representation of medical personnel overall is the largest group, Group A (17 NFs); the other group is Group D, with 1 NF. The level of medical personnel is highest in Groups B, D and E (Table 2, Figure 1). When considering the results for Groups $D$ and $E$, it must be borne in mind that these two groups account for $6.6 \%$ of the NFs (2NFs).

33.3\% of the Pan American NFs reported to have a physiotherapist and the same figure was also reported for doctors, making these two particular medical roles the most common across all the Pan American NFs. 30\% of the Pan American NFs have a nutritionist.

None of the NFs in Groups A and C have a psychologist in contrast to Group B where 3 of the 4 NFs have one. Each NF in Group D and E also have one. 
Table 5. Classification of health priorities among the Pan American NFs according to the total of NFs. Chi-squared measure.

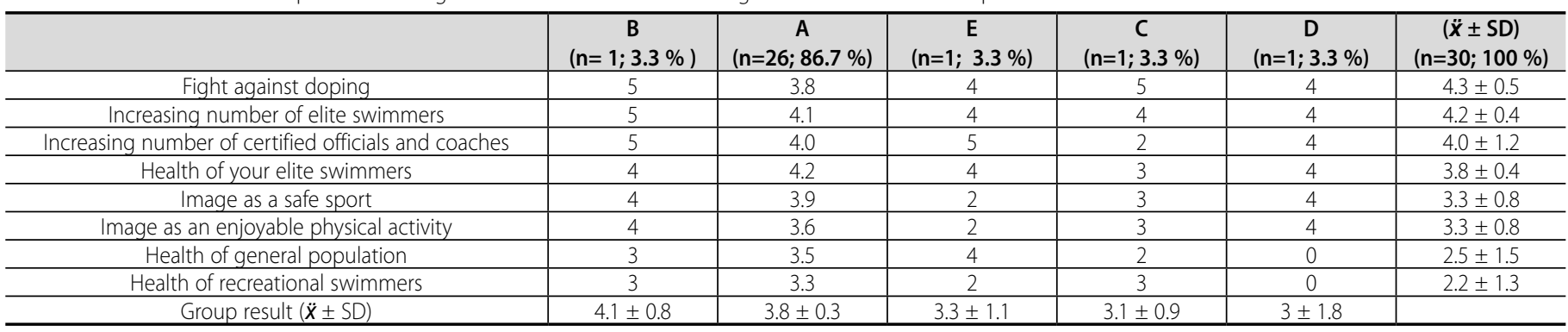

None of the NFs in Groups A, B, C and D reported to have a medical commission, while the $1 \mathrm{NF}$ in Group E confirmed the presence of such a commission.

Dimension 2. Health programmes/ researches and guidelines (Table 4; Figures 2 and 3)

The one NF in Group E reported activity across all of the programmes. In Group A, which accounts for $63.3 \%$ of the NFs, only programmes on drowning are present to a significant degree.

Programmes/research and guidelines details:

$60 \%$ of the NFs reported to have drowning prevention/learn to swim/life guard programmes, making it the most common programme across all of the Groups.

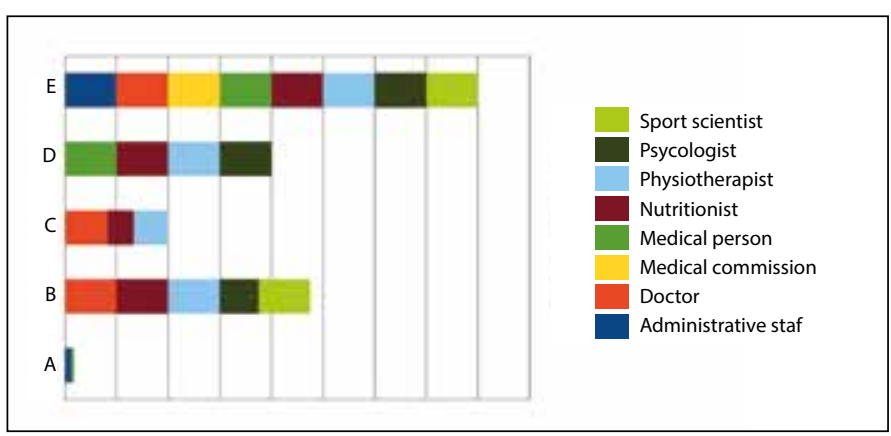

Figure 1. Medical personnel according to the total of NFs in each group.

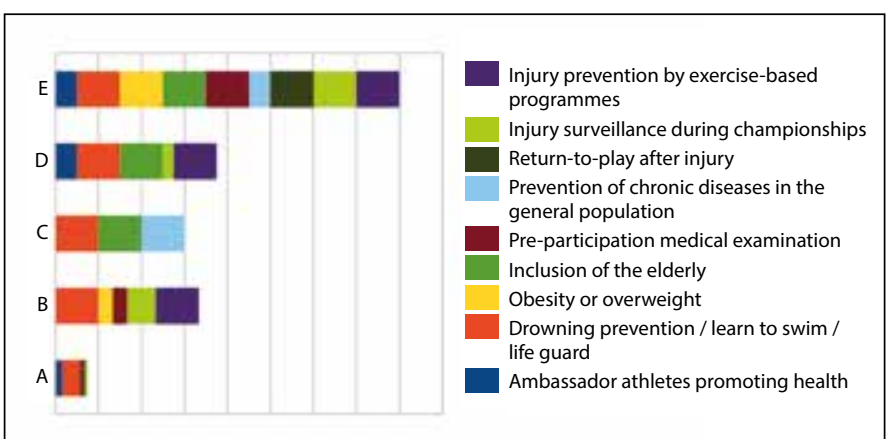

Figure 2. Health promotion programmes, guidelines or research activities according total of NFs.

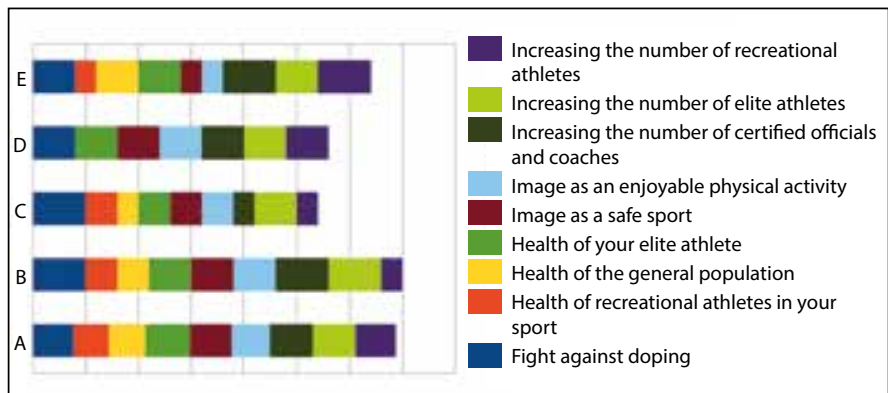

Figure 3. Health promotion programmes, guidelines or research activities according to the total of NFs in each group.
$30 \%$ of the NFs have injury prevention by exercise-based programmes (the second most common of the programmes), 20\% have injury surveillance programmes during the championships and 10\% have return to play after injury programmes.

Programmes for the elderly are the third most common programmes across all NFs (23.3\%). Only the NFs of 3 of the 5 groups (Groups D, E and $C$ ) can be said to be significantly active in relation to programmes focused on this demographic.

Programmes to prevent chronic disease in the general population are the least prevalent of all the programmes; 2 (one NF from each of Group ( and E) have such programmes.

Dimension 3. Health priorities (Table 5; Figures 4 and 5).

The strongest results were reported in the fight against doping category, where the average result among all the NFs was 4.37. The NFs of Groups B, C, and D considered this issue as the highest priority within their NFs.

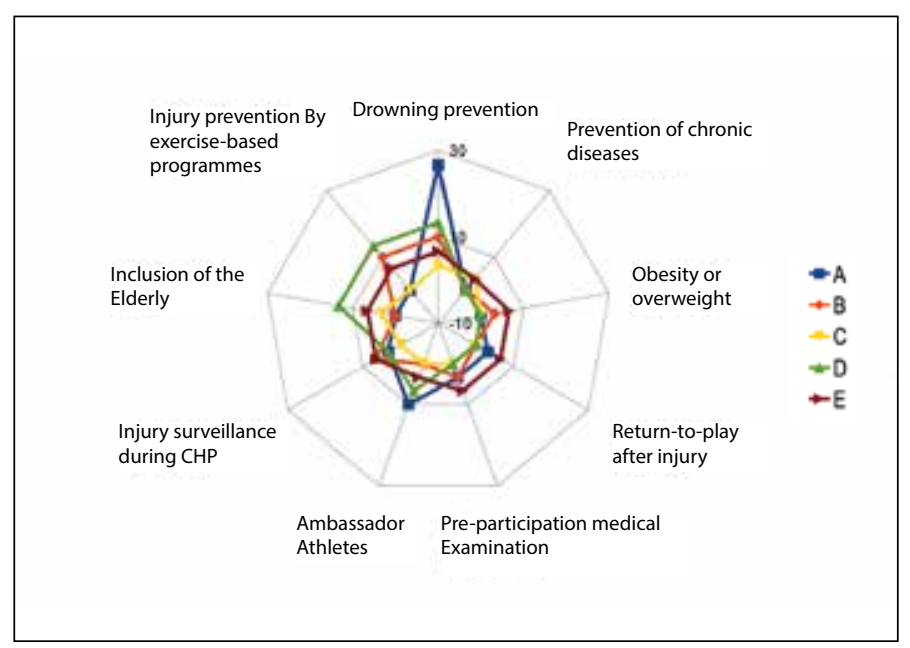

Figure 4. Health priorities according to total of NFs.

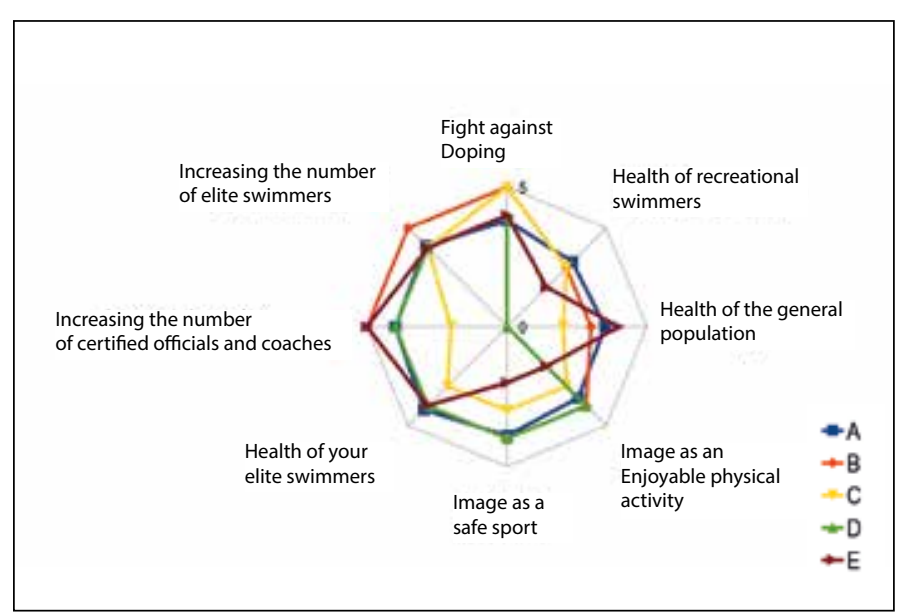

Figure 5. Health priorities according to total of NFs of each group. 
Increasing the number of elite athletes (4.2) and increasing the number of certified officials and coaches (4.0) ranked as the second and third priorities respectively for the NFs overall.

The image of swimming as a safe sport was a mid-ranking priority for majority of the Pan American NFs.

Group A accounts for $86.7 \%$ of the NFs. Group A NFs responded that the health of their elite athletes was their top priority (4.23); increasing the number of elite athletes was the second highest (4.08).

Overall, the health of the recreational athletes and the health of the general population were low priority issues (2.27 and 2.49 respectively).

\section{DISCUSSION}

More than half of the 30 NFs that replied are in Group A meaning that a majority of the NFs that replied share similar experiences in relation to health promotion. The level of medical expertise available to the Group A NFs lags behind that of Groups B, C and E.

Certain commonalities exist across the five groups in relation to physiotherapists and doctors but with a significant difference in attitude towards having a nutritionist, psychologist and sport scientists. The higher level of medical expertise amongst the NFs in Groups B and D and E indicate that these NFs have more potential and resources to develop and implement policies in the area of health promotion. The responses of the Group B NFs demonstrate a focus on providing direct medical support to their athletes (Each of its 4 NFs have a doctors, physiotherapists, nutritionists and sport scientist; 3 have a psychologists).

The low presence of physiotherapists, NFs' low level of injury prevention by exercise-based programmes (only $30 \%$ of the NFs reported to have these programmes) and pre-participation medical examinations (13.3\%) confirms that the Pan American NFs do not have the medical staff required to follow up with the treatment and rehabilitation of injuries ${ }^{17}$.

The one NF in Group E is the only NF that has a medical commission. Sport organisations should include a medical commissions within their governance structure for the purpose of emphasising the importance of sport medicine for athletes ${ }^{18}$.

The Group B and E NFs reported to have the highest results in terms of doctors, physiotherapists, nutritionists and sport scientists indicating that these NFs take a more holistic approach to their athletes' health, focusing not only on their physical but also on their mental wellbeing.

The majority of NFs do not implement health related programmes on a widespread basis. The exceptions to this trend are the Group E NFs which have programmes across all the categories.

Drowning prevention programmes are the most prevalent of the health programmes run by the NFs (60\%). Even in Group A, where the overall level of health related programmes is low, 8 of the 19 NFs have drowning prevention programmes. FINA implements the "Swimming for All" programmes which target only some specific NFs ${ }^{14}$. We did not find any results that would suggest the reason(s) as to why the presence of drowning prevention programmes among the NFs is significantly higher than the presence of the other indicated programmes.

Overall programmes for the elderly was the third most common programme implemented (23,3\%).The FINA and UANA Masters competitions are open to older athletes, demonstrating an interest on the part of FINA and UANA to target the older and recreational athlete demographic. However, there is still room for improvement at the NF level.

\section{Injury related programmes}

The FINA Medical Rules emphasise the protection and promotion of the athlete's health during training and competition and FINA carries out comprehensive injury surveillance at their Events ${ }^{12,13}$. However, the results show that this policy has not trickled down to a significant degree to many of the NFs yet. Just $20 \%$ of them run such programmes at their own championships. Overall, the importance that the NFs attribute to these programmes is low. The 19 NFs of Group A did not exceed 3.3\% in any of the 4 injury related categories. On the other hand, the results in relation to the two NFs of Group E show a consistent approach among them to such programmes with high results in each category. Group B, $E$ and $D$ favour injury prevention by exercise programmes over injury surveillance during the championship, pre-participation medical examination and return to play programmes.

The low level of interest in the health of the general population suggests that NFs regard this as an issue that is not within their area of responsibility.

\section{Dimension 3. Health priorities.}

The fight against doping was the highest priority issue among the Pan American NFs. From an NF perspective, ensuring that their elite athletes are adequately informed about and protected against the dangers of doping is a key pillar in protecting their health.

The health of their elite athlete ranked as the fourth most important issue (3.84) for the NFs. It must be borne in mind that, on a practical level, a NF will require adequate medical staff and programmes to achieve this and the results show that this is not the case among most of the Pan American NFs. There appears to be an inconsistency between the attitudes of the NFs on the fight against doping and the protection of the health of their elite athletes. The long term negative effect of doping on athletes health is well documented leading one to question how the fight against doping could be a top priority for the Pan American NFs while, at the same time, the protection of their elite athletes' health ranks only as a mid-level priority? This would indicate that NFs do not associate doping with health and regard anti-doping as a key issue as they fear the effects of the considerable sanctions associated with an anti-doping violation.

Increasing the number of certified officials and coaches was ranked as the third priority for the NFs overall, behind increasing the number of elite athletes (4.21). Pan American NFs are currently receiving support through the FINA Development Programmes for coaches and officials, with the relatively high priority placed by the Pan American NFs on this topic indicating a certain trickle-down effect from these FINA programmes.

The issue of swimming as a "safe sport" was fifth ranked priority of nine (3.6/5). USA Swimming ${ }^{19}$ has adopted detailed policies in relation to this area. Team doctors can play a major role in the prevention and early detection of sexual harassment and abuse in sport making the need for all NFs to have ${ }^{20}$. As noted above, this is not the case yet in all NFs

The health of recreational athletes and generation population were the lowest ranked priority issues overall. The lack of health promotion policies for recreational athletes is a missed opportunity on the part of national and international sports federations and there is a need to create policy to support and motivate national federations and IFs to address the health and welfare of non-elite athletes ${ }^{11}$. The relatively low level of NFs that have programmes in relation to the elderly and prevention of chronic disease indicates the lack of emphasis placed by NFs on the general population. The results show that NFs are possibly missing out on an opportunity to use the health advantages of swimming to increase the overall popularity of their sport among certain demographics.

\section{CONCLUSIONS}

In general the medical structures of the Pan American NFs are under developed. FINA's programmes in relation to injury surveillance and 
reporting have not trickled down to a significant degree to the Pan American NFs. The lack of such policies by the Pan American NFs prior to and during their championships is evidence of this. Even though drowning programmes are prevalent, overall the results show that the Pan American NFs are more concerned with the results of their elite athletes rather than seeing themselves as having a wider societal impact in terms of health.

\section{ACKNOWLEDGEMENTS}

The authors highly appreciate the co-operation of the Pan American National Swimming Federations and their staff who responded to this survey providing data for this study.

All authors declare no potential conflict of interest related to this article.

AUTHORS' CONTRIBUTIONS: Each author made significant individual contributions to this manuscript. CPD (0000-0001-7989-6687)*, JCDM (0000-0002-9937-5229)*, NRC $(0000-0002-6172-004 X)^{*}$ and BCM (0000-0002-0576-1744)* were the main contributors in the drafting of the manuscript. NRC evaluated the data used for the statistical analysis. We have reviewed and we approve the final version of the manuscript. ${ }^{*} \mathrm{ORCID}$ (Open Researcher and Contributor ID).

\section{REFERENCES}

1. Fédération Internationale de Natation. Protection and Promotion of the Athlete's Health during Training and Competition. In: Fédération Internationale de Natation. Medical Rules [internet]. Lausanne: FINA. 2008. p. 3-4 [access 2016 march 9]. Disponível em: <http://www.fina.org/sites/default/files/rules-print-pdf/8765.pdf>.

2. Hardman AE, Stensel DJ. Physical Activity and Health: The evidence explained. $2^{\text {nd }}$ ed. London: Routledge: 2009. p.269-90.

3. Fuller CW, Junge A, Dvorak J. Risk management: FIFA's approach for protecting the health of football players. Br J Sports Med. 2012;46(1):11-7.

4. Flørenes TW, Nordsletten L, Heir S, Bahr R. Recording injuries among World Cup skiers and snowboarders: a methodological study. Scand J Med Sci Sports. 2011;21(2):196-205.

5. Alonso JM, Edouard P, Fischetto G, Adams B, Depiesse F, Mountjoy M. Determination of future prevention strategies in elite track and field: analysis of Daegu 2011 IAAF Championships injuries and illnesses surveillance. Br J Sports Med. 2012;46(7):505-14.

6. Hägglund $M$, Waldén M, Magnusson $H$, Kristenson $K$, Bengtsson $H$, Ekstrand J. Injuries affect team performance negatively in professional football: an 11-year follow-up of the UEFA Champions League injury study. Br J Sports Med. 2013;47(12):738-42.

7. Waldén M, Hägglund M, Ekstrand J. UEFA Champions League study: a prospective study of injuries in professional football during the 2001-2002 season. Br J Sports Med. 2005;39(8):542-6.

8. Bere T, Alonso JM, Wangensteen A, Bakken A, Eirale C, Dijkstra HP, et al. Injury and illness surveillance during the 24th Men's Handball World Championship 2015 in Qatar. Br J Sports Med. 2015;49(17):1151-6.

9. Lacoste A, Hannafin J, Wilkinson M, Smith M, Oswald D, Rolland JC. Athlete health and safety in rowing: editorial by the FISA (rowing) Sports Medicine Commission. Br J Sports Med. 2014;48(21):1523-4
10. Bere T, Kruczynski J, Veintimilla N, Hamu Y, Bahr R. Injury risk is low among world-class volleyball players: 4-year data from the FIVB Injury Surveillance System. Br J Sports Med. 2015;49(17):1132-7.

11. Mountjoy $M$, Junge $A$. The role of International Sport Federations in the protection of the athlete's health and promotion of sport for health of the general population. Br J Sports Med. 2013;47(16):1023-7.

12. Mountjoy M, Junge A, Alonso JM, Engebretsen L, Dragan I, Gerrard D, et al. Sports injuries and illnesses in the 2009 FINA World Championships (Aquatics). Br J Sports Med. 2010;44(7):522-7.

13. Mountjoy M, Junge A, Benjamen S, Boyd K, Diop M, Gerrard D, et al. Competing with injuries: injuries prio to and during the 15th FINA World Championships 2013 (aquatics). Br J Sports Med. 2015;49(1):37-43

14. International Swimming Federation. FINA Swimming for All, Swimming for Life"Programme [Internet]. [acesso em 2016 march 9]. Disponível em: http://www.fina.org/content/swimming-all-\%E2\%80\%93-swimming-life.

15. Union Americana de Natacion. UANA Leadership [Internet]. [access em 2016 march 9]. Disponível em: <https://www.teamunify.com/SubTabGeneric.jsp?team=uana\&_stabid_=58275>

16. FIMS Interfederal Commission. Survey on the Importance of Medicine in International Sports Federations. Lausanne: FIMS; 2011

17. Dijkstra P, Geertsema L, Geertsema C, Benzarti N. Providing Medical Services To Aquatic Athletes. Aspetar. 2015;4(8):462-5.

18. Engebretsen L, Steffen K. Protection of the elite athlete is the responsibility of all of us in sports medicine Br J Sports Med. 2015;49(17):1089-90

19. USA Swimming Safe Sport Handbook [Internet]. [access em 2017 August 2]. Disponível em: http:// www.metroswimming.org/safety/Safe-Sport-Handbook-FINAL.pdf

20. Marks S, Mountjoy M, Marcus M. Sexual harassment and abuse in sport: the role of the team doctor. $\mathrm{Br}$ J Sports Med. 2012;46(13):905-8. 